\title{
ФОРМУВАННЯ КУЛЬТУРОЛОГІЧНОЇ КОМПЕТЕНТНОСТІ МАЙБУТНІХ УЧИТЕЛІВ ПОЧАТКОВОЇ ШКОЛИ: ДІЯЛЬНІСНИЙ ПІДХІД
}

Анотація. Метою статті є здійснити аналіз, систематизацію й узагальнення теоретичного й практичного досвіду з проблеми реалізації діяльнісного підходу у дослідженні формування культурологічної компетентності майбутніх учителів початкової школи. Автором здійснений аналіз діяльнісного підходу в інтеграції із процесним і особистісним підходами з опертям на значущість особистісних властивостей майбутніх учителів початкової школи й врахуванням специфіки управлінсько-ситуативних аспектів професійної діяльності. Діяльнісний підхід у формуванні культурологічної компетентності майбутніх учителів початкової школи у професійній підготовці трактуеться як впровадження комплексу процесуально-технологічних способів фрормування й розвитку культурологічної спрямованості, культурологічної готовності, культурологічної обізнаності і культурологічної самодостатності в площині активних дій студентів у напрямку культурологічного саморозвитку.

Ключові слова: діяльність, діяльнісний підхід, процесний підхід, особистісний підхід, культурологічна компетентність майбутніх учителів початкової школи.

Hrechanyk Nataliia

Oleksandr Dovzhenko Hlukhiv National Pedagogical University

\section{FORMING THE CULTUROLOGICAL COMPETENCE OF FUTURE PRIMARY SCHOOL TEACHERS: AN ACTIVITY APPROACH}

Summary. The aim of the article is systematization and generalization of theoretical and practical experience on realization of activity approach in studying the problem of formation of culturological competence of future primary school teachers. The author carried out the analysis of the activity approach in integration with the process and personal approach based on the importance of personal properties of future primary school teachers and taking into account the specificity of the managerial and situational aspect of his professional activity and identified the following components: internal factors (personal), external causes (situational), managerial (procedural), technological factors (activity). The article states that the effectiveness of the implementation of cultural competence depends on the ability of the primary school teacher to adapt to environmental conditions that are characterized by constant change. In this regard, the active approach is a tool to determine the optimal ways and methods of forming cultural competence of future primary school teachers in professional training and methods of its implementation and improvement. Thus, cognitive activity of students in the process of learning, scientific, independent activity in the direction of mastering the profession by students contributes to the acquisition, perception, awareness of professional, general and culturological knowledge and determines the improvement of professionally important characteristics of students, becoming a means of forming cultural competence of future primary school teachers. So, in essence, the active approach in the formation of culturological competence of future primary school teachers in professional training is a complex of ways to develop culturological orientation, culturological readiness, culturological awareness and culturological self-sufficiency in the plane of active actions of culturological self-development.

Keywords: activity, activity approach, process approach, personal approach, cultural competence of future primary school teachers.

$\Pi^{2}$ останока проблеми. Модернізація підготовки сучасних учителів у закладах вищої освіти базуеться на формуванні загальної культури особистості, що сприяе підвищенню якості профресійної підготовки. В свою чергу, обгрунтування теоретико-методологічних основ даного процесу дозволяе відобразити його цілісний і системний характер із врахуванням формувальної, розвивальної і виховної складових. У цьому контексті діяльнісний підхід є методологічною основою фрормування фрахових характеристик студентів вишу й дозволяе вивчати освітній процес, як комплекс елементів діяльності, реалізація яких сприяє засвоєнню особистісно-профресійних і загальнокультурних знань, умінь і навичок.

Даний підхід спрямований на вивчення активності здобувачів вищої освіти через призму генезису, змісту і структури категорії «діяльність». У цьому контексті формування і розвиток професійної вправності майбутніх учителів початкової школи у межах освітнього процесу грунтуеться на теорії діяльності (О. Леонтьєв, С. Рубінштейн), сутністю якої є психологічний розвиток особистості, в якому діяльність покладена в основу визначення спрямованості активності людини. Цей фракт обумовлюе необхідність реалізащії діяльнісного підходу в дослідженні культурологічної компетентності майбутніх учителів початкової школи.

Аналіз останніх досліджень і публікацій. Проблему діяльності досліджували фрілософи: Л. Буєва, Е. Ільєнков, В. Коган, О. Маргуліс, Е. Маркарян та ін., психологи: К. АльбухановаСлавська, Л. Анщифрірова, О. Асмолов, Г. Балл, В. Давидов, О. Запорожець, I. Зимняя, М. Каган, Г. Суворова та ін., і педагоги: О. Абдуліна, Н. Кузьміна, В. Сластьонін, О. Щербаков, Е. Юдін та ін.

Так, для нашого дослідження становить інтерес концепщія розвитку вищих психічних фрункщій Л. Виготського; положення та ідеї теорії діяльності Б. Ананьєва, А. Бодалева, А. Леонтьева, Б. Ломова, С. Рубінштейна, Б. Теплова; теорії поетапного формування розумових дій П. Гальперіна, Н. Та- 
лизіної, Г. Ельконіна; психолого-педагогічні теорії про сутність і процес формування умінь і навичок А. Дмитрієва, Е. Кабанова-Меллер, Н. Менчинської. Відзначимо, що пріоритетна роль діяльнісній сорері відведена у дослідженнях управлінської культури педагогів (Л. Васильченко), інформаційної культури майбутніх учителів початкової школи (А. Коломієць), загальнокультурної компетентності особистості й учителів гуманітарних спеціальностей (С. Зубчевська, I. Шумілова) та ін.

Виділення раніше невирішених частин загальної проблеми. Попри таку увагу до реалізації діяльнісного підходу в процесі дослідження психолого-педагогічних явищ залишається не визначеними місце і роль означеного підходу у форммуванні культурологічної компетентності майбутніх учителів початкової школи.

Мета статті. Здійснити аналіз, систематизацію й узагальнення теоретичного й практичного досвіду з проблеми реалізації діяльнісного підходу в дослідженні формування культурологічної компетентності майбутніх учителів початкової школи.

Виклад основного матеріалу. У copepi вищої освіти діяльнісний підхід дозволяе розглядати профресійно-педагогічну діяльність, як систему ефрективних способів і засобів фрормування й розвитку особистості студентів. По-перше - це відповідальні й усвідомлені дії суб'єктів освітнього процесу, як викладачів так і студентів, спрямовані на ефрективність процесів виховання й самовиховання, по-друге - це продуктивна педагогічна суб'єкт-суб'єктна взаємодія, у напрямку передачі загальнолюдського й професійного досвіду, потрете - це організація освітнього простору з метою формування вмотивованості майбутніх фрахівців початкової освіти до саморозвитку, стимулювання потреби, інтересу до здійснення педагогічної діяльності за принципами моральності, духовності й культури в широкому сенсі. За таким підходом вивчення процесу формування культурологічної компетентності майбутніх учителів початкової школи у профресійній підготовці передбачає взаємообумовленість змісту освіти й навчання 3 практичною активністю майбутніх фрахівців.

Відповідно до діяльнісного підходу провідним фрактором у навчанні й вихованні є діяльність. За термінологічними джерелами діяльність визначається як: «застосування своєї праці до чого-небудь; робота, заняття, активність, діяння... Праця, дії людей у якій-небудь галузі... Функціонування, діяння органів живого організму; icнування, життя... Виявлення сили, енергії чогонебудь» [9, с. 774]; «спосіб буття людини у світі, здатність вносити в дійсність зміни» [2, с. 374]; «специфічно людська форма активного ставлення до довкілля, зміст якої складає його доцільна зміна і перетворення» [14, с. 151].

Словникове трактування поняття «діяльність» значно розширюють і поглиблюють відомі вчені психологи. Наприклад, М. Каган зауважуе, що діяльність людини - це знаряддя вдосконалення соціального й природного середовища існування. За таким баченням провідною діяльністю людини стає адаптащія природного й соціального середовища до власних потреб. У цому контексті вчений визначив три види діяльності людини: перетворювальну, пізнавальну й ціннісно-оріентаційну. Перетворювальна діяльність характеризуеться активністю, яка призводить до змін реального й до створення нового в реальному середовищі. Пізнавальною діяльністю є така активність суб'єкта, котра спрямована на вивчення об'єкта, не впливаючи на нього, й сприяє утворенню нового продукту в когнітивній сфері особистості в якості знань про об’єкт. Об'єктами пізнавальної і перетворювальної діяльності є природа, суспільство, людина й особистість, яка щось пізнає. Ціннісно-орієнтаційна діяльність надае людині інформацію про цінності, а не про об'єктивні їі характеристики. Також, М. Каган виокремлюе колунікативний вид діяльності, який узагальнююче відображає особливості «суб'єкт-суб'єктного» взаємозв'язку [4]. Л. Виготський визначає домінантну роль вищих людських психічних процесів у діяльності особистості, бо вони з'являються тільки у взаємодії людини з людиною «...і лише потім починають виконуватись індивідом самостійно» [1, с. 198-199].

За О. Лєонтьєвим, діяльність людини, залежить від ії статусу в сощіумі, від конкретних умов і обставин. За думкою вченого, провідною характеристикою діяльності є предметність, яка визначає зміст і спрямованість діяльності. Поряд із цим, О. Леонтьєв розглядає діяльність як системи, які містять комплекс базових елементів, що взаємопов'язані між собою: організаційна (суб'єкт, процес, предмет, умови, продукт діяльності) й соціально-психологічну (мета, мотив, спосіб, результат). 3 огляду на зазначене вище, діяльність детермінується предметом й опосередковується і регулюеться його образом, як своїм суб'єктивним утворенням. У такому розумінні діяльність складається з окремих дій, які мають якісну складову (способи (операціiі)) і утворюють процес, що характеризуеться постійними трансрормаціями в динаміці. У зв'язку з цим, дії співвідносяться $з$ цілями, а операції з умовами. Дані складові постійно змінюються, тому змінюються дії і їх операщійний склад (О. Беляк).

$\mathrm{У}$ загальному розумінні «діяльність» трактується як практика, в основі якої усвідомлюється і перетворюється об'єктивна дійсність, що є основою розвитку людського суспільства, рушійною силою й критерієм істинності пізнання, а її структуру складають: потреба, мета, мотив, дощільна діяльність, предмет, засоби і результат [6; 13]. $\mathrm{У}$ цьому розумінні така діяльність - це мотивуюча активність, яка містить мету й спрямована на певний об'єкт, реалізується за допомогою конкретних засобів, що призводить до результатів.

Отже, від мети, предмета, засобу й результату залежить характер діяльності. На рівні цілепокладання мета діяльності - це вектор і траєкторія прагнень особистості, механізм розгортання в практищі операщійного компоненту діяльності, за допомогою якого реалізуються ті чи ті дії. Поряд із цим, ефективність будь-якої діяльності забезпечується певними умовами й обставинами, в площині яких особистість реалізуе відповідні знання, уміння і навички.

Тому, у вивченні процесу формування культурологічної компетентності майбутніх учителів початкової школи з позицій діяльнісного підходу ми виходимо 3 того, що конкретна діяльність являє собою «складну сукупність процесів, що об'єднані загальною спрямованістю на досягнення певного результату» [6, с. 520] і є «...специфрічно людською формою відношення до навколишнього світу, зміст якого складає його дощільну зміну та перетворення 
в інтересах людини; умова існування суспільства», тобто є механізмом соціалізації особистості, в тому числі, через опанування професії [12, с. 386].

У визначенні ролі і місця суб'єктивного чинника у формуванні культурологічної компетентності майбутніх учителів початкової школи вихідним положенням $є$ психологічний принцип єдності свідомості й діяльності, відповідно до якого свідомість не може бути поза діяльністю, як і діяльність без свідомості. У зв'язку з цим, саме особистість виступає головною одиницею цих процесів. 3 погляду психолого-педагогічного трактування особистості це система психічних, психофрізіологічних і соціально-психологічних властивостей: потреби, мотиви, інтереси, світогляд, почуття, переконання, ознак темпераменту й характеру, здібностей, особливостей психічних процесів (пізнавальних: відчуття, сприймання, пам'яті, мислення, уяви, мови, уваги; емоційно-вольових: почуттів, волі) (А. Петровский). Соціальна природа структури особистості відображається світоглядом, потребами, інтересами, ідеалами, устремліннями, морально-етичними характеристиками тощо. Тому, метою освіти є всебічний і вільний розвиток особистості у спеціально-організованих обставинах [2]. Так, розуміння «діяльності», як складного процесу зоріентовуе нас на вивчення проблеми оволодіння особистістю професійних знань і вмінь, визначаючи діяльність, що є здійсненням людиною того чи іншого ставлення до світу, яке відповідає потребам [6].

За таким принципом психологи обгрунтовують те, що конкретний внутрішній психічний стан обумовлений специфрікою практичної діяльності суб'єкта, а зовнішня практична діяльність інтеріоризуеться й набуває ознак внутрішньої психічної діяльності. Діяльнісний підхід містить такі положення про діяльність: предметність, активність, єдність зовнішньої і внутрішньої діяльності, механізми інтеріоризації й екстеріоризації $[3 ; 6 ; 11]$.

3 ціеї позищії діяльнісний підхід вивчає психолого-педагогічні явища в суб'єктному й діяльнісному контекстах, де свідомість і діяльність взаємоінтегровані [11]. Тож, суб'єктні механізми людської діяльності, відображені: у зв'язку між суб'єктом i об'єктом, який полягає в переході об'єкта в його суб'єктивну форому, і разом з тим, у діяльності здійснюеться також перехід у об’єктивні висновки (А. Леонтьев); в інтерпретації людиною діяльності, як конкретного її ставлення до дійсності, в якому проявляються властивості комплексного характеру, покладена домінуюча роль особистісних властивостей індивіда у впливі на зовнішне середовище (С. Рубінштейн). Даний підхід є пріоритетним методом дослідження активності усіх сырер особистості, бо «...діяльність є основою, засобом і вирішальною умовою розвитку особистості» [8, с. 78].

Діяльнісний підхід у контексті особистісного (О. Бондаревська, В. Лозова, О. Пехота, С. Сисоєва, А. Хуторський, І. Якиманська та ін.) відображає конкретно-науковий рівень методології дослідження й забезпечуеться використанням відповідних ідей, які обумовлені необхідністю побудови суб'єкт-суб'єктних стосунків між учасниками освітнього процесу, дозволяе визначити співпрацю, як найвищу форму педагогічної взаємодії, а спільну діяльність вважати фрункціональною властивістю й інтегративним чинником суб'єкт-суб'єктної взаємодії (О. Ліннік). Саме, компетентнісна природа культурологічної характеристики майбутнього вчителя початкової школи свідчить про домінуючу комунікативну ознаку, яка у більшості випадків можлива тільки у безпосередньому монологовому й діалоговому спілкуванні, які є характерними для представників педагогічної профресіі.

На думку І. Шумілової, вивчення питань фрормування загальнокультурної компетентності майбутніх учителів гуманітарних спещіальностей передбачає їх розгляд в особистісно-зорієнтованому й діяльнісному підходах, у контексті яких розуміння діяльнісної характеристики особистості, як мотивованої до самоідентифікації, самореалізації й здатна визначати себе рівноправним суб'єктом суб'єкт-суб'єктної взаємодії, використати власний потенціал культуродоцільно і природовідповідно. Усі ці ознаки особистісно-діяльнісного підходу носять цільовий, проектувальний, моделювальний і технологічний характер, що призводить до визначення оптимального стану профресійної самоідентифікації особистості.

А. Коломієщ вивчала діяльність студентів у контексті системи критеріїв інфрормаційної культури майбутніх учителів початкової школи. Їх практичний зміст представлений автором такими складниками: конструктивний критерій - навички конспектування, редерування, інтегрування, структурування індрормації (культура розумової праці); уміння забезпечити доступ до інфрормації, створювати і розповсюджувати власну інформащію (комунікативна культура); уміння використання ITКТ у навчально-виховному процесі (комп'ютерна грамотність і інформаційна компетентність); дослідницько-творчий критерій - уміння складати розгорнуту характеристику, писати реферати, доповіді, анотащії, ставити наукову проблему та знаходити шляхи їі розв'язання (культура розумової праці); уміння досліджувати інформацію на правдивість, письмово чи усно висловлювати свою точку зору та аргументовано доводити їі (комунікативна культура); готовність застосовувати ITКТ в педагогічних дослідженнях, створенні нових методик і технологій; навички створення телекомунікаційних проектів, застосування комп'ютерних дидактичних ігор (комп'ютерна грамотність та інформаційна компетентність).

За версією О. Федорцової, діяльнісно-процесуальний компонент культурологічної компетентності майбутніх інженерів енергетиків самостійне керування розумовими операціями, оптимальне використання теоретичних знань у практичній площині, фрормування практичних умінь. Автор вирізняе в досліджуваному феномені міжкультурну комунікативну складову, яка $є$ здатністю ефрективно спілкуватися в різних міжкультурних ситуаціях, використовуючи набуті загальнокультурні знання й уміння [13].

Реалізація майбутнім учителем початкової школи культурологічної компетентності у напрямах професійної діяльності передбачає актуалізацію особистістю цілої низки лідерських якостей, які ми позищіонуємо, як складний процес самокерування власними вчинками у досягненні мети. Зокрема, ці дії містять управлінський комплекс знань і вмінь і навички самоменеджменту тощо. У цьому контексті ми звернули увагу на процесний підхід (Л. Файоль). Поняття «процес» е базовим процесного підходу, який близький за змістом до 
діяльнісного, що базуеться на управлінській концепції, згідно з якою управління є динамічна система взаємопов'язаних дій, або фрункцій (М. Мескон). Л. Файоль трактуе даний підхід із позищії сутнісної характеристики поняття «керувати», як здатності передбачати й планувати, організовувати, розпоряджатися, координувати і контролювати. У зв’язку з цим, вчені визначають планування, організацію, мотивацію і контроль взаємозалежними фрункціями управлінських дій (М. Мескон).

Відмітимо, що Л. Васильченко в управлінській культурі педагога виокремлюе когнітивно-діяльнісний колпонент і характеризуе його критеріями, проявом яких є оволодіння педагогом системою профресійно-управлінських знань, знань сучасних технологій менеджменту; сфрормованість логічності, системності й аналітичності мислення й уміння; пізнавальна активність; усвідомлення особистістю реального рівня власної профресійної підготовки до реалізації управлінських фрункцій; усвідомлення потреби й активність особистості у процесі профресійної самоосвіти, самовдосконалення; усвідомлення наявного й потрібного рівня розвитку комунікативних здібностей; аксіологічне засвоєння елементів спілкування; створення нових моделей процесу педагогічного спілкування.

Виконання управлінських фрункцій майбутнім учителем початкової школи реалізації культурологічної компетентності у педагогічній діяльності залежить не тільки від особистісно-профресійного інструментарію, але й від низки умов, які, як відомо, є постійно змінними й часто мало передбачуваними. У зв'язку з цим, важливим є поняття «ситуація», яке $є$ базовим у ситуащійному підході й об'єднуючим елементом із процесним підходом.

Поняття «ситуація» - це комплекс обставин, що впливають на діяльність у конкретний час, яким у контексті поняття «педагогічної ситуації» властива зміна похідних - важливих компонентів діяльності (цілей, завдань, методів і способів досягнення мети) залежно від обставин [3; 5]. Аналіз майбутнім учителем конкретної виробничої ситуащії дозволяе йому здійснити оптимальний добір методичного інструментарію впливу на об'єкт залежно від обставин.

Вище зазначені результати наукових розвідок вчених дозволили у процесі профресійної підготовки вчителів початкової школи вирізнити: етап спеціально-організованого становлення свідомості особистості у напрямку їі виховання, як самодостатнього суб'єкта навчання; активну діяльність майбутніх фрахівців у комунікуванні; опанування різних форм і видів діяльності фрахового спрямування; формування вмінь, визначення мети, планування діяльності, організація та контроль, аналіз і оцінювання результатів [6]. За таким баченням цілі й завдання діяльнісного підходу, які реалізовуються в дослідженні проблеми формування культурологічної компетентності майбутніх учителів початкової школи, сприяють удосконаленню процесуальної складової у напрямку оволодіння суб'єктами освітнього процесу педагогічною діяльністю у культурологічному вимірі в цілісному сприйнятті.

Отже, з позиції діяльнісного підходу профресійна підготовка майбутніх учителів початкової школи - це процес, який відтворюе структуру діяльності усіх суб'єктів педагогічної взаємодії.
В системі професійної підготовки студент не лише опановуе знання про майбутню діяльність, але й опановуе способи дій щодо успішної реалізації особистісного й профресійного потенціалу. Фахові знання можна засвоїти, лише оперуючи ними, тобто системно актуалізуючи їх. А культурологічні вміння доцільно розглядати як послідовності діяльностей, що містять окремі дії та операцій, тому що «діяльність не існує інакше, окрім як у фрормі дій або ланцюга дій» [6]. Таким чином, діяльнісний підхід передбачає зв'язок змісту профресійної освіти майбутніх учителів початкової школи з їхньою майбутньою педагогічною діяльністю [10].

Здійснений аналіз діяльнісного підходу в інтеграції із процесним і особистісним підходами з опертям на значущість суб'єктивних якостей майбутніх учителів початкової школи й врахуванням специфіки управлінсько-ситуативних аспектів професійної діяльності дозволив виокремити такі їі складники: внутрішні чинники (особистісні), зовнішні чинники (ситуативні), управлінські чинники (процесуальні), технологічні чинники (діяльнісні).

На нашу думку, загальна культура особистості майбутнього фрахівця інтегрована у профресійний компонент підготовки i визначається не тільки змістом його культурологічних знань, а й рівнем защікавленості студента у культурному розвитку, розумінням і вирішенням профресійних проблем за принщипами моральності й духовності, прагненням до саморозвитку, самовдосконалення за законами культури в широкому сенсі. Також ефрективність реалізащії культурологічної компетентності залежить від того, на скільки вчитель початкової школи здатен адаптуватися до умов навколишнњого середовища, які характеризуються постійними змінами.

У зв'язку з цим, діяльнісний підхід дозволяе визначити оптимальні способи й прийоми фрормування культурологічної компетентності майбутніх учителів початкової школи у профресійній підготовці та методи їі реалізащї й удосконалення. Теоретико-методологічні засади даного підходу дозволяють: закцентувати увагу на особистісних i профресійно спрямованих здібностях майбутніх фрахівців у співвідношенні із особливостями культурологічної компетентності через розгортання профресійної підготовки у межах вивчення дисщиплін загального ииклу (блок норлативних дисииплін - українська мова за професійним спрямуванням, історія та культура України, сучасна українська мова з практикумом, іноземна мова; дисиипліни вибіркового блоку - етика й естетика, соціологія, релігієзнавство, основи демократії тощо); посилити формування складників культурологічної компетентності через зміст дисциплін проббесійного ииклу (блок норлативних дисииплін - теорія навчання, теорія виховання, історія педагогіки, основи педагогічної майстерності, сценічного та екранного мистецтва з методикою; педагогічні технології в початковій школі та основи інклюзивної освіти, образотворче мистецтво з методикою навчання, музичне мистецтво 3 методикою навчання, фрахові методики; дисиипліни вибіркового блоку - комплекс навчальних курсів із музичного мистецтва, комплекс навчальних курсів iз образотворчого мистецтва тощо); обгрунтувати методичну систему формування культурологічної компетентності у відповідності до специфріки педагогічної діяльності вчителів початкової школи. 
Висновки і пропозиціі. Отже, діяльнісний підхід фрормування культурологічної компетентності майбутніх учителів початкової школи - це організація освітнього процесу, де пріоритетними є активна, продуктивна, пізнавальна діяльність студентів в опануванні культурологічних знань, умінь і навичок.

Таким чином, пізнавальна діяльність студентів у процесі навчальної, наукової, самостійної діяльності у напрямку опанування фраху студентами сприяе засвоєнню, сприйняттю, усвідомленню професійних, загальних і культурологічних знань і детермінуе вдосконален- ня фахово важливих характеристик студентів, стаючи засобом формування культурологічної компетентності майбутніх учителів початкової школи. Отже за своєю сутністю діяльнісний підхід у формуванні культурологічної компетентності майбутніх учителів початкової школи у професійній підготовці - це впровадження комплексу процесуально-технологічних способів формування й розвитку культурологічної спрямованості, культурологічної готовності, культурологічної обізнаності і культурологічної самодостатності в площині активних дій культурологічного саморозвитку.

\section{Список літератури.}

1. Выготский Л.С. Развитие высших психических функций. Из неопубликованных трудов. Москва : Изд-во Акад. пед. наук, 1960. 500 с.

2. Гончаренко С.У. Український педагогічний словник. Київ : Либідь, 1997. 374 с.

3. Деятельностный подход в психологии. URL: www.dic.acamic.ru/dic.nsf/psihologic

4. Каган М.С. Человеческая деятельность (Опыт системного анализа). Москва : Политиздат, 1974. 328 с.

5. Коляда М. Використання діяльнісного підходу при формуванні інформаційної культури майбутніх економістів. Педагогіка і психологія профбесійної освіти. 2003. № 1. С. 46-58.

6. Леонтьев A.А. Что такое деятельностный подход в образовании. URL: wwwschool21.000.ru

7. Людиномірність гармонізації культурно-освітнього простору особистості : методологія, експертиза та психолого-педагогічні рецепції : монографрія / [Аносов І.П., Молодиченко В.В., Троїцька Т.С. ; за заг. ред. Т.С. Троїцької]. Мелітополь : Видавничий будинок ММД, 2012. 378 с.

8. Несвірська Т.В. Формування загальнокультурної компетентності майбутніх учителів іноземної мови в процесі професійної підготовки : дис. ... канд. пед. наук : 13.00.04. Житомир, 2012. 277 с.

9. Новий тлумачний словник української мови: в 4 т. Т. 3. Київ : Анонім, 2001. 774 с.

10. Оліяр М.П. Теоретико-методичні засади формування комунікативно-стратегічної компетентності майбутніх учителів початкових класів. 13.00.02., 13.00.04. дис. докт. пед. наук. Одеса, 2016. 577 с.

11. Рубинштейн С. Л. Основы общей психологии : в 2 т. Москва : Педагогика, 1989. Т. 2. 328 с.

12. Советский энциклопедический словарь. Москва : Советская Энциклопедия, 1979. 1600 с.

13. Федорцова О.Г. Формування культурологічної компетентності майбутніх інженерів енергетиків у процесі вивчення гуманітарних дисциплін : автореф. дис. ... канд. пед. наук : 13.00.04. Житомир, 2016. 23 с.

14. Философркий энциклопедический словарь [Гл. ред. Л.Ф. Ильичев, П.Н. Федосеев, С.М. Ковалев, В.Г. Панов]. Москва : Сов. энциклопедия, 1983. 151 с.

\section{References:}

1. Vyhotskiy, L.S. (1960). Razvitie vysshykh psikhicheskikh funktsii. Iz neopublykovannykh trudov [The development of higher mental functions. From unpublished works]. Moscow: Izd vo Acad. ped. science, 500 p.

2. Honcharenko, S. U. (1997). Ukrainskyi pedahohichnyi slovnyk [Ukrainian Pedagogical Dictionary]. Kyiv: Lybid, 374 p.

3. Deiatelnostnyi podkhod v psikholohii [Activity approach in psychology]. Access mode: www.dic.acamic.ru/dic.nsf/ psihologic

4. Kahan, M.S. (1974). Chelovecheskaia deiatelnost (Opyt systemnoho analiza) [Human Activity (Experience of System Analysis)]. Moscow, 328 p.

5. Koliada, M. (2003). Vykorystannia diialnisnoho pidkhodu pry formuvanni informatsiinoi kultury maibutnikh ekonomistiv [Using an active approach in forming the information culture of future economists]. Pedagogy and psychology of professional education, no. 1, pp. 46-58.

6. Leontev, A.A. Chto takoe deiatelnostnyi podkhod v obrazovanyy [What is a proactive approach in education]. Access mode: www.school21.000.ru

7. Liudynomirnist harmonizatsii kulturno-osvitnoho prostoru osobystosti: metodolohiia, ekspertyza ta psykholohopedahohichni retseptsii (2012). [Harmonization of the cultural and educational space of the individual: methodology, expertise and psychological and pedagogical guidelines]. Monograph. [Anosov I.P., Molodychenko V.V., Troitska T.S. ; by ed. T.S. Troitskoi]. Melitopol: MMD Publishing House, 378 p.

8. Nesvirska, T.V. (2012). Formuvannia zahalnokulturnoi kompetentnosti maibutnikh uchyteliv inozemnoi movy v protsesi profesiinoi pidhotovky [Formation of general cultural competence of future foreign language teachers in the process of professional training]. Diss. ... cand. ped. sciences: 13.00.04.

9. Novyi tlumachnyi slovnyk ukrainskoi movy: v 4 t. T. 3 (2001). [A new explanatory dictionary of the Ukrainian language: in 4 part. P. 3]. Kyiv, 774 p.

10. Oliiar, M.P. (2016). Teoretyko-metodychni zasady formuvannia komunikatyvno-stratehichnoi kompetentnosti maibutnikh uchyteliv pochatkovykh klasiv [Theoretical and methodological bases of formation of communicative and strategic competence of future primary school teachers]. Diss. ... cand. ped. sciences: 13.00.02., 13.00.04.

11. Rubynshtein, S.L. (1989). Osnovy obshchei psikholohii: v 2 tomah [Basics of General Psychology : in 2 part]. Moscow: Pedagogical, $328 \mathrm{p}$.

12. Sovetskiy entsyklopedicheskiy slovar (1979). [Soviet Encyclopedic Dictionary]. Moscow: Soviet Encyclopedia, 1600 p.

13. Fedortsova, O.H. (2016). Formuvannia kulturolohichnoi kompetentnosti maibutnikh inzheneriv enerhetykiv $u$ protsesi vyvchennia humanitarnykh dystsyplin [Formation of culturological competence of future power engineers in the process of studying humanitarian disciplines]. Zhytomyr: Abstract of the dissertation. for the degree of Candidate of Pedagogical Sciences 13.00.04, 23 p.

14. Fylosofskiy entsyklopedicheskiy slovar (1983). [Philosophical encyclopedic dictionary]. Moscow: Soviet Encyclopedia, 151 p. 